\title{
THE STORIES OF FAVOURING. GENESIS 4, 4-5
}

\section{HISTÓRIAS DE FAVORECIMENTO. GÊNESIS 4, 4-5}

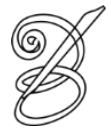 \\ Alexandru GAFTON* \\ "Alexandru Ioan Cuza” University of Iași \\ Iași, Romania \\ Adina CHIRILA $\breve{A}^{* *}$ \\ West University of Timișoara \\ Timișoara, Romania
}

\begin{abstract}
However faithful it may appear, any translation is the result of the translator's interpretation of the source-text, influenced by various elements present in the broad circumstances of that particular translating activity. In some cases, this fact alters or adds a new layer of meaning to the original text. The present paper explores the case under Gen. 4, 4-5, where, by introducing a linguistic variation - namely dw'ron, -ou (toV) / qusiva, -a" (hJ) (in kaiV ejpiV toi'" dwvroi", v. 4, and kaiV ejpiV tai'" qusivai", v. 5) - instead of the monotony

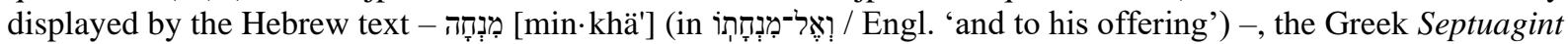
provides the reader with the possibility of condemning Cain before he commits the crime.
\end{abstract}

Keywords: Bible studies. Textual alteration. Mosaic theology. Hebrew-Greek translation. Biblical exegesis.

Resumo: Por mais fiel que possa parecer, qualquer tradução é o resultado da interpretação do texto-fonte pelo tradutor, influenciado por vários elementos presentes nas amplas circunstâncias dessa atividade de tradução em particular. Em alguns casos, esse fato altera ou acrescenta uma nova camada de significado ao texto original. $O$ presente trabalho explora o caso nos itens Gen. 4, 4-5, nos quais, ao introduzir uma variação lingüística - a saber, dw'ron, -ou (toV) / qusiva, -a" (hJ) (in kaiV ejpiV toi" dwvroi", v. 4, and kaiV ejpiV tai " qusivai", v. 5) - ao invés

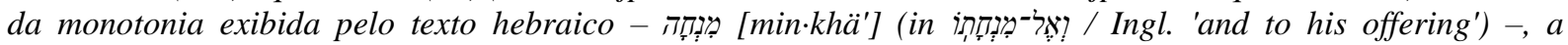
Septuaginta grega dá ao leitor a possibilidade de condenar Caim antes que ele cometa o crime.

Palavras-chave: Estudos bíblicos. Alteração textual. Teologia mosaica. Tradução hebraico-grego. Exegese bíblica.

RECEBIDO EM: 20 de junho de 2019

ACEITO EM: 30 de julho de 2019

PUBLICADO EM: abril 2020 


\section{Introduction}

ranslating implies adapting certain contents to the specific forms of a target-language.
Ideally, the content of a source-text is rendered undistorted, and only its characteristics
of form suffer modifications which are inevitable especially in the case of translations between two languages as different as the Hebrew, a Semitic language, and the Greek, an IndoEuropean language. Any translation is jeopardised by the translator's interpretations according to his/her capacities or interests. When performed on purpose, changes of form generate changes of meaning, sometimes profound, which get to alter radically the meaning of the original text. Such a situation can be found in Gen. 4, where one finds the story of Adam and Eve's two sons. The original Hebrew text, for reasons accounted for in the following paragraphs, presents the shepherd brother as the victim of the ploughman brother. Putting aside the killing itself however, the distinction between the two brothers is completely unmarked throughout the text, and initially there is no contrast between their personalities or their actions. With the Greek translation, the pursuit of a motivation for the crime and the struggle to strengthen the plausibility of the story accentuate the distinction between Cain and Abel, and eventually the former gets to be condemned before committing the sin.

The distinction gift-sacrifice. In Gen. 4, 4-5, telling the story of Cain and Abel placing their offerings before Yahweh, the Septuagint makes use of a couple of terms that mark a change in comparison with the Hebrew version:

Thus,

LXX: kaiV ejpei`den oJ qeoV" ejpiV !Abel kaiV ejpiV toi`" dwvroi" aujtou` / ejpiV deV Kai>n kaiV ejpiV tai'" qusivai" aujtou` ouj prosevscen,

while

WLC:

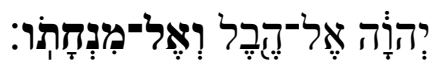

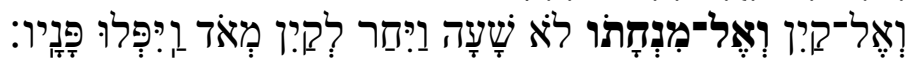

[Engl., KJV: And the Lord had respect unto Abel and to his offering; but unto Cain and to his offering he had not respect].

The Masoretic text offers the same word in v. 4 and 5 for 'offering': 'gift, tribute, offering', 'offering made to God, of any kind, whether grain or animals' (HE, s.v.)

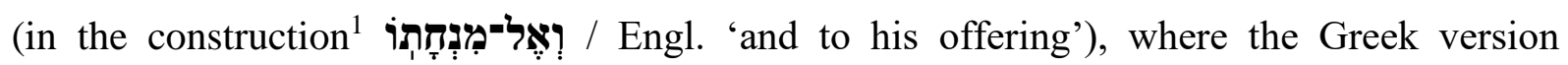
introduces a lexical variation, as: dw'ron, -ou (toV) / qusiva, -a" (hJ) (in kaiV ejpiV toi`" dwvroi", v. 4, and kaiV ejpiV tai'" qusivai", v. 5). 
Several questions arise concerning this discrepancy: when did it occur, and on what contextual grounds?; can it legitimately sustain a differentiating hermeneutic over the sacred text, so as to justify the different faith of the two brothers (and, further on, of mortals, in general) with regard to Yahweh?

\section{The source/s}

Early rabbinic literature already discusses various cases of textual 'alterations' in Greek (in the Septuagint), in comparison with the original Hebrew sacred writings. The exegetic tradition operates with several such lists that contain a variable number of Hebrew-Greek textual differences in the Pentateuch (between 10 and $18^{2}$ ). None of these lists refers to LXX Gen. 4, 4-5, but this does not mean that it should not be discussed. Even if we were to operate with the same interpretation ${ }^{3}$ that the dominant Hebrew tradition seemed to have of alteration ${ }^{4}$, we would expect these lists to be lacunary, offering rather the certitude of a phenomenon's manifestation, and not the rigorous inventory of this phenomenon's products ${ }^{5}$.

The phenomenon in question is fed by multiple factors that fundamentally refer to the human element which uses language, whether Hebrew or Greek, though in different epochs and stages of writing, and with various degrees and nuances concerning the understanding of what 'text intrusion' might mean. It has been shown that what can be perceived as difference between the Hebrew Pentateuch and the Greek Septuagint ${ }^{6}$ stems from: a) the existence of multiple variants of the Hebrew text itself $f^{7}$; b) a certain translation technique; c) the concretization of exegetical preferences; d) misunderstanding the text; and/or e) translators'/scribers' linguistic option, within the limits provided by Greek or by the context in which the translation has been made. $^{8}$

The hypothesis of existing parallel Hebrew versions for Gen. 4, 4-5, with different words for 'gift, offering', which would have escaped registration in the Masoretic text, but which would have influenced the Hellenised Hebrew translator, is not absurd. This would, in fact, easily explain why the Greek version presents a variation where the "source-text" calls for a monotonous linguistic action.

By the time of re-producing the sacred text of the Jews in Greek, the Mosaic sacrificial ritual was using a series of strictly specialized terms referring to various types of sacrifices regulated for various occasions, situations, motives, purposes ${ }^{9}-$ a reality that could have had an influence over the linguistic material that was to be subjected to translation. Taking into account the details ${ }^{10}$ of the story that reveal the context in which Cain and Abel come with their 
offerings to Yahweh, the terms that could have been used in the narration (as it could have been transmitted towards the end of the $3^{\text {rd }}$ century B.C.) could have been, theoretically, two, central in the semantic field of the 'individual jubilatory sacrifice': מְִָּדָה [min·khä'] 'gift, offering' and ת ת [to-daw'] 'thank-offering'.

However, an argument against this point of view derives from the anthropologic analysis of the behaviour of the primitives concerning the facts that could be observed, but escaped their rational understanding. According to this type of scrutiny, the two sacred actions designated by min·khä'] and [to-daw'] are not apt to be confused with each other: they emerged at different ages of the humankind and correspond to some major differences regarding the knowledge that the human being could possess about the essence of things, causality, human determinism, etc. The former - which appears in the form of the offering of the first products of one's labour - is grounded on ancestral totemism and animism: the individual (a sheaf of grain, a lamb from the flock, or something else) represents mystically the entire species with whom the humans deal at that moment (in the case presented in Gen. 4, domesticated species: vegetal or animal); and the sacrificed individual thus offered as a gift to the spirit of nature enables the returning of what the spirit of nature has given to people, to nature itself; thus the consumption of the elements that have been taken from nature is harmless for humans. ${ }^{11}$ The latter reveals a later mental synthetization of a transcendental entity that dominates nature and disposes of all nature's resources, as well as of the human beings that populate this nature as it likes; the benevolence of this entity must be maintained through constant recognition of its manifestation, and through repeated homages of thanks performed according to a ritual whose setting up has been attributed to the entity itself. In consequence, the terminology is not interchangeable in this case.

Nevertheless, by the time the people that had created these religious manifestations became preoccupied with the preservation, in one way or another, of myths, these two sacred actions were already susceptible of superposition or inclusion of one into the other. The initial holidays and sacred actions do suffer transformations, and sometimes blend, so that the relevance of the distinction requested by the anthropological perspective may be considerably diminished.

The hypothesis of a semantic relativization is therefore plausible. It would then follow that in the translator's consciousness the two terms refer to extralinguistic realities sufficiently similar in order to allow for a variation game. However, the text itself does not offer proof for 
this particular reasoning. 'Thankfulness', expressed as thank-offering (i.e. הדָּ [to-daw']), never makes use of the other term, i.e. [min·khä'] ${ }^{12}$, in the entire Pentateuch.

Moreover, besides being involved in the description of a sacred action, when it functions as the name of the holiday and the name of the offering itself, [min narration of some laic interactions, as in Gen. 32, 13, 18, 20, 21; 33, 10; 43, 11, 15, 25, 26 bearing the meaning of 'gift', in different concrete forms. ${ }^{13}$ This type of linguistic usage concords with the situation described in the first section of Gen. 4, when all the two descendants of Adam have to do is to bring some gifts from what they had, without any considerations upon the nature of those possessions. Of a greater importance is, however, the extended context in which their action appears: against the background of a vast and complicated network of rituals historically developed, Cain and Abel's action cannot be but strongly arche-typified; it is the founding action that stands for at least one religious ritual (the sacrifice of the first fruits), and that should not be imperilled by linguistic innovation.If what the Hebrew text offers in Gen. 4, 4-5, as the story of Cain and Abel, but also as a part of a macro-structure that rather enforces control over the construction of the discourse and then restriction regarding any variation of it, does not encourage the employment of a synonymic couple more or less absolute, it follows that the innovation, the alteration operated by the translator has its reasonings outside the text itself: in the capacity of the translator to reason 1) upon the Greek vocabulary, having to operate with terms belonging to the semantic field of 'offering'/'bringing offerings', and/or 2) upon the meanings of the text, which he must convey to a new public.

It is safe to assume that, with the exception of certain situations which have been the object of thorough analyses, the Hebrew-Greek equivalences that emerge in translation stem from a usage that predates the translation itself, and from a cultural and religious environment that was offering, on the one hand, the advantage of a rich terminology describing the myriads of aspects related to religious practices, but also, on the other hand, the risk of an already specialised terminology of a certain cult whose beliefs and practices could not be but rejected by another cult. On the one hand, the Hellenized Hebrew has a rich Greek religious vocabulary at hand; on the other hand, this vocabulary is loaded with the connotative baggage of the Hellenistic religious practices. Thus, the translators of the Septuagint must not only find and establish equivalences, but also reduce or annul de risk of confusion between the two different religious practices, while possessing a good knowledge of the target-language.Such an effort of selection and, consequently, of terminological specialization towards the Mosaic cult is evident, e.g., in the case of מִזְָָָ [miz-bay'-akh] 'lit. a place of slaughter or sacrifice' (EA I, s.v. Altar), 
(see Gen. 8, 20, etc.): in order to translate it the preference constantly goes to the Greek $\theta v \sigma i \alpha \sigma \tau$ piov (a rare form ${ }^{14}$ ), and not to the more common $\beta \omega \mu$ òv. ${ }^{15}$ The former becomes related with the cult of Yahweh (and then, with that of the Christian God):

WLC, Gen. 8, 20

ויבן נח מזבח ליהוה ויקח מכל הבהמה הטהורה ומכל העוף הטהר ויעל עלת במזבח:

LXX, idem

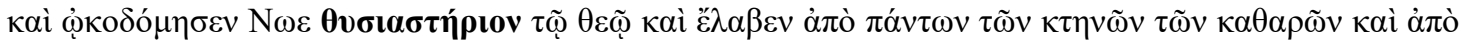

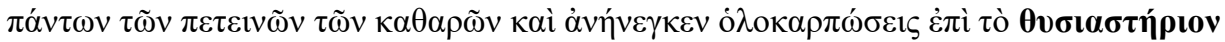

[Engl., KJV: And Noah builded an altar unto the Lord; and took a very clean beast, and of every clean fowl, and offered burnt offerings on the altar],

cf. Math. 5, 23 (ș.cl.):

N-A 1994

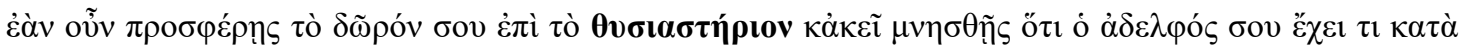
боṽ

[Engl., KJV: Therefore if thou bring thy gift to the altar, and there rememberest that thy brother hath ought against thee];

while the latter remains in the field of a "pagan" practice:

see Acts 17, 23:

N-A 1994

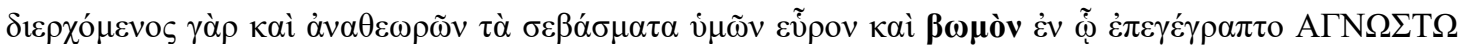

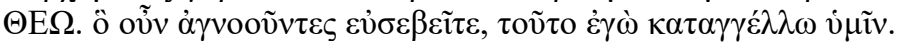

[Engl., KJV: For as I passed by, and beheld your devotions, I found an altar with this inscription, TO

THE UNKNOWN GOD. Whom therefore ye ignorantly worship, him declare I unto you].

\section{Justification}

The situation under Gen. 4, 4-5, if isolated from the rest of the text and from the history of the text's interpretation (as a coherent whole that should be credited with a logic adherent to what the human reasoning considers to be acceptable), was offering the premise of a simple translating solution. However, a translation is never sequentially executed, without consideration for the text as a whole, and - at least in some cases - for the content of the metatexts that accompany it. The purpose of the Septuagint's authors was not that of presenting the readers with a text version upon which they would build up - anew and riskily! - a theology, but to provide the readers with a Greek Tora that would lead to and perpetuate an already existing theology, with all the nuances that have been attached to it along centuries, through the rabbinic hermeneutics. The employment of the dw'ron for Abel's offering, and of qusiva for Cain's offering is interesting, the more so as the study of the Greek version in comparison with its original Hebrew version has created the idea that the former lacks lexical diversity, a characteristic caused by the translator's frequent use of fixed equivalents (Tov 184). Since the 
Hebrew text presents one term in both cases, the existence of two different terms - a traductological effort - in the Greek text points to a certain intention on the part of the translator.

Taking into account their usage in the Greek pre-Septuagintic literature, the semantic extensions and the frequency of the two Greek words under discussion are similar: ${ }^{16}$

dw'ron, -ou (toV): 'offrande aux dieux', 'tribut' < divdwmi 'faire don de', 'offrir' (Bailly, s.v.); 'gift, present, gift of honour', 'votive gift or offering to a god' (Liddell-Scott, s.v.);

qusiva, -a" (hJ): 'sacrifice' < quvw 'offrir un sacrifice aux dieux', 'offrir une victime en sacrifice', 'consulter les dieux en leur offrant un sacrifice' (Bailly, s.v.); 'burnt-offering, sacrifice' (Liddell-Scott, s.v.).

It may be thus assumed that a hypothetical difference in the meaning of one word compared to the other was not the reason for employing both of them in describing the bipolar reaction of god towards Cain and Abel's gesture.

One might object on the line suggested by Emanuel Tov's observation that, in the evaluation of the meanings of the words in the Greek Pentateuch, one should take into account "the meaning of the words in the pre-Septuagintic stage, the meaning in the Septuagint itself as intended by the translators, and the meaning of the words as quoted from LXX" (94; our emphasis). Thus, it would be possible that the translator meant to transmit a different meaning (regarding the nature or the quality, or the rightfulness of the offering itself) through qusiva as against dw'ron, semantically nuancing in comparison to what a hypothetical Hebrew-Greek dictionary would have offered him right away... Nevertheless, it is the Cain's Greek qusiva (not the Abel's Greek dw'ron) that appears in harmony with what seems to be an effort to establish a Greek terminology specialized for the Mosaic cult (see supra, the case of $\theta v \sigma \iota \alpha \sigma \tau \rho^{\prime}$ with qusiva).

Rather, the two nouns do not describe discriminatingly the quality etc. of the offering a fact that, if so, would justify, in extremis, Cain's rejection. ${ }^{17}$ The reason for variation is to be linked to a more subtle, and, probably, more complex intention. In the Mosaic theology, the idea of the entire humanity living under the authority of a divinity which acts completely and utterly at its own whim and which has granted itself the right to ignore human ethics (Yahweh does not need a certain action of an individual in order to act in a certain way towards them, as proven by the history of Job) - sometimes possibly by virtue of a higher and absconded reasoning - is neither peripherical, nor reluctantly taught. There is a virtue in recognizing Yahweh's unfairness, and remonstrating with him for it, as in, e.g., Job 10, 2; 13, 2. All of this is for the sake of the opportunity to reiterate the absolute superiority of god, even in the absence 
of the rational understanding of god's actions, as in Job 42, $3 \ldots$ In the case under Gen. 4, 4-5, the original Hebrew text is clear about Yahweh's arbitrary preference, unjustifiable from a terrestrial common-sense, between the two brothers; the Greek version, due to the linguistic option of a translator oriented towards a contemporary reader possessing a good knowledge of the Greek language, overbids, augmenting the message of a God as such, up to a possible verdict

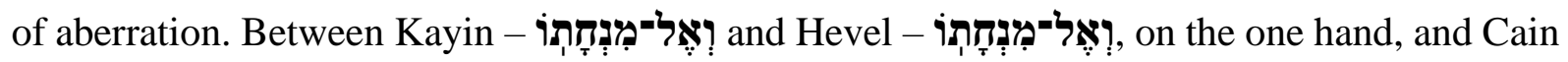
- kaiV ejpiV tai'" qusivai" and Abel - kaiV ejpiV toi" dwvroi", on the other hand, the difference is not of meaning, but of calibre. And the difference is not meant to draw attention to what Cain might have done till the moment of his sacred action.

Inevitably though, and even in the absence of any grasping of this augmenting effect, the linguistic option of the translator had an effect over the perceived identity of the two individuals involved in the story. The reader, observing the "simple" use of two words, ${ }^{18}$ made a clear-cut distinction between the two brothers, from the first moment. They became completely separated in the minds of the readers, beginning with their names, and up to the most minute details.

\section{Beyond the letter of the book}

The story of Cain and Abel seems to be a mere creation of the Judean imagination, a case rather rare among the stories of the Old Testament (from the story of Eve's creation out of Adam's rib, so similar to the Sumerian myth of Enki and Ninhursag, ${ }^{19}$ to the tendency to exaggerate the biblical ages, expressed also in various Sumerian myths about antediluvian kings, the common elements between the stories from the Old Testament and the Antique legends and myths of the Sumerians and the Greek are abundant). What is it that triggered the creation of the legend? And what is the purpose of the legend itself? At some point in their existence, the Hebrew tribes tried to explain, first to themselves, why Yahweh, their merciful father, had condemned the human race to perpetual toil, suffering, and decay. But also it seems plausible that this legend is the echo of a conflict that, way before the legend set-up, had erupted between the nomad tribes of shepherds and herd-keepers, and the groups of population that were beginning to develop a sedentary way of life, based on the cultivation of the soil. Such conflicts are abundantly depicted in Sumerian writings, but none of these narrations contain the detail of the cultivator killing the shepherd. The Hebrews were, however, herd-keepers, and Abel, the shepherd, became in their version of the story Yahweh's favourite, and the innocent victim of Cain, the cultivator. 
In the biblical narration, the dynamics result from the struggle between certain counterparts. If and where these counterparts are, through their nature, weak, the translator (who re-tells the story anew) intervenes with his tendency to reinforce them, and to reveal their most differentiating aspects, at points of maximum opposition.

One must point out that, when they are actually offering their gifts to Yahweh, neither Cain nor Abel is explicitly connoted one way or another. On the contrary, Yahweh is expecting exactly the same thing, from both of them, and when he seems displeased, for some reason, with Cain's gift, God is addressing him in the fatherliest way possibly... The similarity between the two sons of Adam is even more conspicuous in the Quran (Surah V), where they do not bear any name, their occupation is not revealed, and no information is given about their age. In our opinion, the distinction between the two appeared in order to satisfy the interests of the civilization which was manipulating the legend in a very well-defined context, not the Divinity. If one of the two brothers had to kill the other, and thus lose the bigger fight, the cultivator of the soil had to be that brother, ${ }^{20}$ regardless of his name.

\section{BIBLIOGRAPHY}

ANET = Ancient Near East Texts Relating to the Old Testament, James B. Pritchard (Ed.), Princeton, Princeton University Press, 1969.

Bailly, M.A., Dictionnaire Grec-Français, Hachette, Paris, 1901.

Chirilă, Adina, Alexandru Gafton. "Dinamica traducerilor biblice în raport cu ambiguitatea contextuală a termenilor. Studiu de caz: Levitic, 11, 22". Analele Științifice ale Universității «Ovidius» Constanța. Seria Filologie, Tom XXVII, nr. 2, 2016, pp. 169-178.

---. "Opţiuni de redare a numelor proprii în traducerile biblice. Studiu de caz: numele fiicelor lui Iov (Iov 42: 14)". Analele Științifice ale Universității «Alexandru Ioan Cuza» din Iași, Secțiunea IIIe Lingvistică, LVIII, 2012, pp. 33-43.

---. "They made "a mistake" in Job, 4, 11; why not also in Prov, 30, 30? Implicitly, about limits in philology and the necessity of accepting them". Diacronia, IV/2018, nr. 1(7), 2018, pp. 1-9. http://dx.doi.org/10.17684/i7A105en.

Coranul. Traducere din limba arabă, introducere și note de George Grigore, București, Editura Herald, 2012.

Daniel, Suzanne. Recherches sur le vocabulaire du culte dans la Septante, Paris, Klincksieck, 1966. 
Dogniez, Cécile. “Quelques remarques sur le vocabulaire du travail dans la Bible”. Edited by Eberhard Bons, Jan Joosten, Regine Hunziker-Rodewald, Biblical Lexicology:

Hebrew and Greek Semantics - Exegesis - Translation, De Gruyter, 2015, pp. 243260.

EB I, Encyclopaedia Biblica. Vol. I (A-D). Edited by T.K. Cheyne and J. Sutherland Black, The Macmillan Company, 1899.

Fritsch, Charles T. The Anti-Anthropomorphism in the Greek Pentateuch, Princeton Legacy Library, [1943] 2015.

Gafton, Alexandru. După Luther. Traducerea vechilor texte biblice, Iași, Editura Universității "Alexandru Ioan Cuza", 2005.

$\mathrm{HE}=$ Francis Brown, S.R. Driver, Charles A. Briggs (Eds.), The Brown-Driver-Briggs Hebrew and English Lexicon. Based on the lexicon of William Gesenius, Oxford, Clarendon Press, 1907.

$\mathrm{JE}=$ Jewish Encyclopaedia, la http://jewishencyclopedia.com/

JFAA = Bíblia Português. João Ferreira de Almeida Atualizada, at https://bibliaportugues.com/

Joosten, Jan. "Translating the Untranslatable: Septuagint Renderings of Hebrew Idioms". Edited by R. Hiebert, Translation Is Required: The Septuagint in Retrospect and Prospect, Brill, Leiden / SBL, Atlanta, 2010a, pp. 59-70.

---. "The Aramaic Background of the Seventy: Language, Culture and History". Bulletin of the International Organization for Septuagint and Cognate Studies, 43, 2010b, pp. 53-72.

---. "Trahir pour mieux traduire. La traduction « contradictoire » dans la Septante". Edited by in D. Frey, C. Grappe and M. Wieger, Usages et mésusages de l'Écriture, Presses Universitaires de Strasbourg, Strasbourg, 2014, pp. 19-30.

---. “The Interplay between Hebrew and Greek in Biblical Lexicology: Language, Text and Interpretation". Edited by E. Bons, J. Joosten \& R. Hunziker-Rodewald, Biblical Lexicology: Hebrew and Greek. Semantics - Exegesis - Translation, De Gruyter, Berlin, 2015, pp. 209-223.

---. "Septuagint Greek and the Jewish Sociolect in Egypt". Edited by E. Bons and Jan Joosten, Die Sprache der Septuaginta / The Language of the Septuagint, LXX.H 3

Gütersloher, Gütersloh, 2016, pp. 246-256.

KJV = The Holy Bible. (...), World Bible Publishers, Inc., [s.l.], [s.a.].

Liddell-Scott $=$ Henry George Liddell, Robert Scott, A Greek-English Lexicon, Compiled by... A New Edition Revised and Augmented by Sir Henry Stuart Jones, Oxford, [s.a.]. 
Loisy, Alfred. Essai historique sur le sacrifice, Paris, Nourry, 1920.

LUT. = Luther Biebel. 2017. https://www.bibleserver.com/start/LUT

LXX = Septuaginta, SESB Edition A. Rahlfs and R. Hanhart (Eds.), Stuttgart, Deutsche Bibelgesellschaft, 2006.

N-A1994 = NESTLE-ALAND, Novum Testamentum Graece et Latine, Deutsche Bibelgesellschaft, 1994.

PERSEUS = Perseus Digital Library, la http://www.perseus.tufts.edu/hopper/.

$\mathrm{SB}=$ Sainte Bible contenant l'Ancien et Nouveau Testament avec une traduction française en forme de paraphrase, par le R.P de Carrières, et les commentaires de Menochius, tome premier, Lille, 1843.

$\mathrm{SBP}=$ La Sainte Bible Polyglotte, contenant le texte Hébreu original, le texte Grec des septante, le texte Latin de la vulgate et la traduction française de m. l'abbé Glaire, des introductions, des notes, des cartes et des illustrations par F. Vigoruoux, tome I, A. Roger et F. Chernoviz, Libraires-éditeurs, Paris, 1900.

Sept. I. 2004, Septuaginta. Iov, Inţelepciunea lui Solomon, Inţelepciunea lui Sirah, Psalmii lui Solomon. Volum coordonat de: Cristian Bădiliţă, Francisca Băltăceanu, Monica Broşteanu, Dan Sluşanschi, în colaborare cu Ioan-Florin Florescu, [s.1.], Polirom.

STRONG, James. Greek Dictionary of The New Testament, Albany, 1997.

Tov, Emanuel. The Greek and Hebrew Bible. Collected Essays, Brill, 1999.

VUL. = Biblia Sacra Juxta Vulgatam Versionem (Vulgate Latin Bible). Edited by R. Weber, B. Fischer, J. Gribomont, H.F.D. Sparks, and W. Thiele [at Beuron and Tuebingen].

WLC $=$ Westminster Leningrad Codex, Westminster Hebrew Institute, 2006. https://www.blueletterbible.org/versions.cfm\#wlc

\footnotetext{
* Alexandru GAFTON - Student of Professor Vasile Arvinte, Professor, PhD, at the "Alexandru Ioan Cuza" University of Iași, Romania. Evolutionary linguist and philologist, with a Humean naturalist perspective. Author of studies that attempt to understand the dynamics of language, thought, society and the evolution of relations between them; author of critical editions of old Romanian texts; translator and commentator of works in the fields of diachronic linguistics and the history of Christianity, evolutionism and mentalities. "Alexandru Ioan Cuza" University of Iași, Romania. Iași, Romania.

Academic site: http://media.lit.uaic.ro/catedra/new/membrii/gafton

Google Scholar: https://scholar.google.com/citations?user=v6kC4YYAAAAJ\&hl=ro

ORCID: https://orcid.org/0000-0002-1706-169X

E-mail: algafton@gmail.com

** Adina CHIRILA - Associate Professor at the West University of Timișoara, Romania. Bachelor's degree in Romanian/English (2000), West University of Timișoara, Roumania. Master's degree with specialization "Romanian language in synchrony and diachrony. Controversial issues" (2002), West University of Timișoara, Romania. PhD in Humanities - Philology (2008), West University of Timișoara, Romania. Linguist and
} 
philologist, whose work's pillars are observation, proof and reasoning. Author of two books and over fifty articles and reviews concerning the history of the Romanian language, textology, Romanian philology, and diachronic linguistics; author of a critical edition of a $17^{\text {th }}$ century Romanian text; translator of works in the fields of evolutionism, genetics and the philosophy and history of science; member of the Editorial board of Diacronia (www.diacronia.ro); member of German Cognitive Linguistics Association, and of Répertoire des historiens de la traduction, Ottawa. West University of Timisoara, Department of Romanian Languages. Timişoara, Romania.

Academic curriculum: https://uvt-ro.academia.edu/AdinaChirila/CurriculumVitae

Google Scholar: https://scholar.google.com/citations?user=HPsRw2sAAAAJ\&hl=en

ORCID: https://orcid.org/0000-0003-4979-0675

E-mail: adina.chirila@e-uvt.ro

${ }^{1}$ Which is reproduced as such in translations that follow the Hebrew text: "Et respexit Dominus at Abel, et ad munera eius. / Ad Caïn vero, et ad munera illius non respexit." (VUL.); "Und der Herr sahe gnediglich an Habel und sein Opffer. / Aber Kain und sein Opffer sahe er nicht gnediglich an." (LUT.); "L'Eternel porta un regard favorable sur Abel et sur son offrande. / Mais il ne porta pas un regard favorable sur Caïn et sur son offrande." (SB); "Ora, atentou o Senhor para Abel e para a sua oferta, / mas para Caim e para a sua oferta não atentou" (JFAA); "And the Lord had respect unto Abel and to his offering. / But unto Cain and to his offering he had no respect." (KJV); etc.

${ }^{2}$ See Tov, 1-ff.

${ }^{3}$ A definition of the concept of 'alteration' does not occur in the rabbinic literature; it would cover however - upon the analysis of each and every case - different types of intrusion in the text regarded as the archetype.

${ }^{4}$ For inventories and commentaries of various differences between the Hebrew and Greek versions of the Old Testament, see Joosten 2014, 2015, 2016; Tov 1999; Daniel 1966, etc.

${ }^{5}$ See Tov (15): "The contents of lists of this type are largely a matter of chance [...] This list does not purport to represent the most conspicuous alterations and indeed anyone will easily find much more far-reaching differences between the LXX and M[asoretic]T[ext], as for instance in the order of chapters and subject matter at the end of Exodus. What the passages in the list have in common is that they pertain to some central issues" (our emphasis). ${ }^{6}$ Rigorously speaking, using the singular in both cases is misleading: both texts were formed as a synthesis of several rather partial separate individual or collective literary products; thus, speaking of an original Hebrew text, or of an original Greek text is, at best, a simplification of the matter.

${ }^{7}$ Not always identifiable.

${ }^{8}$ See Tov 1999, 6, 15; see, especially for b), Fritsch [1943] 2015; for c), d) and e), Joosten 2010a,b, 2014, 2015; Daniel 1966, especially p. 18-19; for e), although outside the Pentateuch, see also Chirilă 2012, 2018, Chirilă \& Gafton 2016.

${ }^{9}$ Presented in Leviticus, they are mainly: the holocaust (olah); the meal-offering (minhah); the sin-offering (hatat); the trespass-offering (asham); the peace-offerings (shelamim), including the thank-offering (todah) and the voluntary or vow-offering (nedabah or neder). See JE, s.v. Sacrifice, at http://jewishencyclopedia.com/articles/12984-sacrifice .

${ }^{10}$ It is about a moment in the history of the humankind when, after the first cataclysm in the relation between man and his creator, - the falling, the acquiring of knowledge, God's punishment, etc. - things begin to settle to a natural course, on which people live and multiply, earn their living, and periodically reiterate their belief in transcendent forces through sacred actions. There are still no other actions or violations of an otherwise still inexistent set of rules, that would have required a sacrifice for sin. The primitive context of the story of Cain and Abel rejects the reference, through language, to a complex ritual of expiation, or of individual or collective purification.

See also JE, sv Abel. - Critical View, at http://jewishencyclopedia.com/articles/216-abel: "The Biblical account of Abel comes from one writer $(\mathrm{J})$ only, and is so brief and fragmentary that much is left to speculation when we try to get the original form of the story. The name itself cannot be satisfactorily explained, as it is only clear that the narrative comes from a very old tradition. The Assyrian word for son is hablu, and the derivation from a Babylonian source seems to be quite probable."

${ }^{11}$ See Loisy 1920, V.III.

${ }^{12}$ See Lev. 7, 12, 13, 15; 22, 29.

${ }^{13}$ See and compare: Gen. 32, 13-15: "And he lodged there that same night; and took of that which came to his hand a present for Esau his brother; Two hundred she goats, and twenty he goats, two hundred ewes, and twenty rams, Thirty milch camels with their colts, forty kine, and ten bulls, twenty she asses, and ten foals." (KJV); Gen. 43, 11: "And their father Israel said unto them, If it must be so now, do this; take of the best fruits in the land in your vessels, and carry down the man a present, a little balm, and a little honey, spices, and myrrh, nuts, and almonds" (KJV); etc. 


\footnotetext{
${ }^{14}$ According to EB I, s.v., " $\theta v \sigma \iota \alpha \sigma \tau$ piov is unknown in classical literature, being apparently confined to biblical,

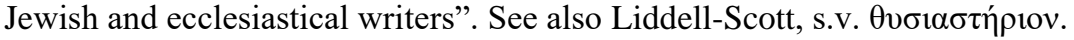

${ }^{15}$ For some details, see Tov (186).

${ }^{16} \mathrm{Cf}$. Perseus, at http://www.perseus.tufts.edu/hopper/.

${ }^{17}$ It has been groundlessly speculated that the gift (namely what Abel brings, Gr. dw'ron) is whole; while a part of the offering (namely what Cain brings, Gr. qusiva) returns to the person who offered it - a false presumption, since a burnt offering may be total, as in the case of the holocaust. It has also been said that Abel's gift is the superior gift, because it consists of meat, while Cain's is offensive because it consists of grains and vegetables - a perspective as false as the previous one, since it contradicts what God himself prescribed through the Law of Moses: cf. Vulgata, Deut. 12, 11: "in loco quem elegerit Dominus Deus vester ut sit nomen eius in eo illuc omnia quae praecipio conferetis holocausta et hostias ac decimas et primitias manuum vestrarum et quicquid praecipuum est in muneribus quae vovistis Domino"; JFAA, loc. cit.: "Então haverá um lugar que o Senhor vosso Deus escolherá para ali fazer habitar o seu nome; a esse lugar trareis tudo o que eu vos ordeno: os vossos holocaustos e sacrifícios, os vossos dízimos, a oferta alçada da vossa mão, e tudo o que de melhor oferecerdes ao Senhor em cumprimento dos votos que fizerdes."

${ }^{18}$ The fact that, not knowing Hebrew and the original text, the reader did not know that the translator had produced an alteration is irrelevant here.

${ }^{19}$ See Anet, 31969, (40-41).

${ }^{20}$ See Dogniez (250-251), where the authors discusses Cain's occupation in comparison to Abel's: “c'est alors le

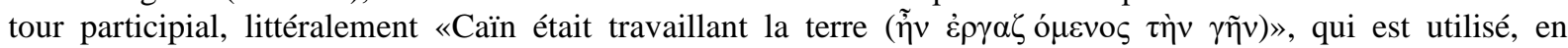
undécalque de la syntaxe hébraïque, et constitue plutôt une description péjorative de Caïn (c'est ainsi du moins que le comprendra Philon d'Alexandrie en Agric 20-25)" (our emphasis).
} 